\title{
The Term of Nefer in Ancient Egyptian Conception
}

Taher Abdelhamid

Faculty of Tourism and Hotels, Fayoum University

\begin{abstract}
The Ancient Egyptian record their actions and doings on Temples and tombs' walls. Thus these writings commemorate their civilization. All writing had different expression and terms. Between these terms was the term of nefer. As, a result the idea and importance of this paper arise. This current study aims to shed light on the term of nefer in Ancient Egyptian conception and takes just examples to illustrate the meaning of the term only; show the different ways of its writing; indicate the different meaning of the term; refer to the term in personal and places names; point out the term in Egyptian gods descriptions; and finally show the term in personal names and titles. Throughout this study, the term nefer had different meaning according to the determinative. Furthermore, it used as a god and mentioned in personal names and titles.
\end{abstract}

Keywords: Nefer, Egyptian Conception, God, Ennead.

\section{Introduction}

Ancient Egyptian writings are the way that made civilization survives until now. These writings contained many scripts (Hieroglyphic, Hieratic, Demotic, and Coptic). Moreover, the Ancient Egyptian language had a lot of terms and expressions.

The term nefer $₫$ was a trilateral sign (Gardiner, 1994). This sign of nefer (F35) means in nature the heart and windpipe (Gardiner, 1994; Allen, 2010). Firstly, the sign was written with details 8 , then the details were disappeared in the late period and the sign was "fonan and Grapow, 1971).

Furthermore, the following ideogram signs had the same phonogram of $n f r$

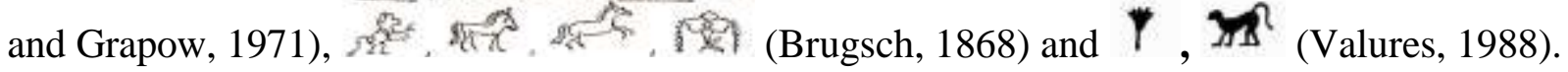

\section{The different methods of writing the term nefer}

The term nefer was written by different ways as follows: to (Ranke, 1935), (Lutz, 1927), बI (Erman and Grapow, 1971), (Grrdiner, 465).

The different meaning of the term nefer

The following table had the different meaning of the term nefer in ancient Egyptian Language.

Table 1: The different meaning of the term nefer

\begin{tabular}{|l|l|l|l|l|}
\hline No. & Word & Transliteration & \multicolumn{1}{|c|}{ Translation } & References \\
\hline 1 & $t^{2}$ & $n f r$ & $\begin{array}{l}\text { Good, Kind, perfect, happy, } \\
\text { faire, well }\end{array}$ & $\begin{array}{l}\text { Meeks, } \\
\text { Dickson, 2006 }\end{array}$ \\
\hline 2 & $\begin{array}{l}\text { geodness } \\
3\end{array}$ & $n f r$ & goode, 1909 & Sehte \\
\hline 4 & Crown of Upper Egypt & Sehte, 1909 \\
\hline 5 & $n f r$ & $n f r$ & door & $\begin{array}{l}\text { Brugsch, 1868 } \\
\text { Bickson, 2006; }\end{array}$ \\
\hline
\end{tabular}


International Journal of Heritage, Tourism and Hospitality Vol. (12), No. (1/2), March, 2018 By: Faculty of Tourism and Hotels, Fayoum University

\begin{tabular}{|c|c|c|c|c|}
\hline 6 & $t^{2}-$ & $n f r$ & Grave or tomb & Lesko, 2002, \\
\hline 7 & t & $n f r$ & not & Gardiner, 1994 \\
\hline 8 & $t_{\infty}^{\infty} \infty$ & $n f r p w$ & There isn't, not & Bates, 2004 \\
\hline 9 & t & $n f r(w)$ & Zero, nil & $\begin{array}{l}\text { Dickson, 2006; Bates, } \\
2004\end{array}$ \\
\hline 10 & 尚的 & $n f r$ & Pure gold & Lesko, 2002, \\
\hline 11 & 10 & $n f r$ & plant & Brugsch, 1868 \\
\hline 12 & $t^{*}<$ & $n f r$ & Warmth, heat, fire & $\begin{array}{l}\text { Brich, 1967; Meeks, } \\
1998\end{array}$ \\
\hline 13 & 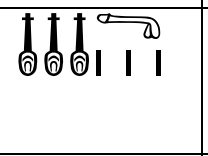 & $n f r$ & youth & $\begin{array}{lr}\text { De Buck } & \text { and } \\
\text { Gardiner, } & 1950 ; \\
\text { Meeks, 1998 } & \end{array}$ \\
\hline 14 & $t_{0}^{2}$ & $n f r$ & Handsome & Faulkner, 1988 \\
\hline 15 & $t_{8} 8000$ & $n f r$ & grain & $\begin{array}{l}\text { Erman and Grapow, } \\
1971\end{array}$ \\
\hline 16 & 蚛 & $n f r$ & The foal & $\begin{array}{l}\text { Erman and Grapow, } \\
1971\end{array}$ \\
\hline 17 & tesths & nfri & Couch, bench & $\begin{array}{l}\text { Erman and Grapow, } \\
1971\end{array}$ \\
\hline 18 & $t^{\circ}$ & nfr ti & bless & Brich, 1967 \\
\hline 19 & $1^{2}<$ & nfryt & End or bottom & $\begin{array}{l}\text { Erman and Grapow, } \\
1971\end{array}$ \\
\hline 20 & trante & nfry.t & Tiller rope & Faulkner, 1988 \\
\hline 21 & 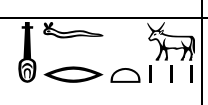 & $n f r t$ & Cattle & Sehte, 1909 \\
\hline 22 & 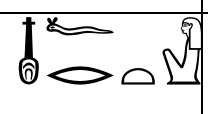 & ffrwt & Faire and young women & Meeks, 1998 \\
\hline 23 & 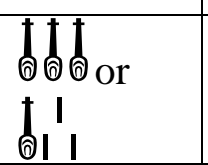 & nfrw & $\begin{array}{l}\text { Beauty, goodness or end } \\
\text { (period of time). }\end{array}$ & $\begin{array}{l}\text { Sethe, 1909, Dickson, } \\
2006\end{array}$ \\
\hline 24 & 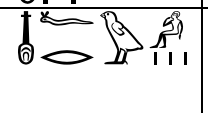 & nfrw & Recruits & $\begin{array}{l}\text { Schulman, } \\
\text { Jones, } 2000\end{array}$ \\
\hline 25 & 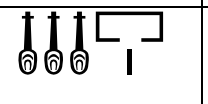 & nfrw & End part of the building & $\begin{array}{l}\text { Erman and Grapow, } \\
1971\end{array}$ \\
\hline 26 & $1 \operatorname{lom}_{n}^{111}$ & nfrw & Deficiency & Brich, 1967 \\
\hline 27 & ब1' & nfrw & $\begin{array}{l}\begin{array}{l}\text { In Min god titles, refer to } \\
\text { phallus }\end{array} \\
\end{array}$ & Wilson, 1997 \\
\hline
\end{tabular}


International Journal of Heritage, Tourism and Hospitality Vol. (12), No. (1/2), March, 2018 By: Faculty of Tourism and Hotels, Fayoum University

\begin{tabular}{|c|c|c|c|c|}
\hline 28 & $\mathbb{w}_{0}^{\infty}$ & $m h n f r$ & render full account & Cauville, 1997 \\
\hline 29 & 10 & $b w n f r$ & good & Faulkner, 1988 \\
\hline 30 & $\overrightarrow{00}$ & $\check{s p} n f r$ & good event & $\begin{array}{l}\text { Erman and Grapow, } \\
1971\end{array}$ \\
\hline 31 & 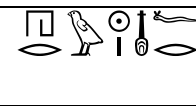 & $h r w n f r$ & Good day & $\begin{array}{l}\text { Erman and Grapow, } \\
1971\end{array}$ \\
\hline 32 & $1^{2}=\ldots$ & $n f r . n . i$ & It went well with me & $\begin{array}{l}\text { Gardiner, } \\
\text { Meeks, 1998; }\end{array}$ \\
\hline 33 & $t^{2} \infty$ & $r-n f r$ & In good part & Loprieno, 1995 \\
\hline
\end{tabular}

\section{The term nefer as a god}

The god Nefer appeared in ancient Egyptian texts by two ways: the first, with the determinative of gods as follows: in Pyramid Texts (Spell 683)

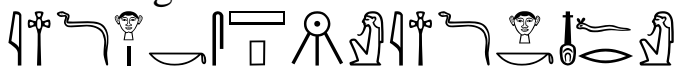

i nd hr.k šps 'I nd hr.k nfr O, sheps (god), protect my face, O, nefer; protect my face (Samuel, 1952; Faulkner, 1978; Timofey, 2012).

In addition, God Nefer appeared in two Spells of Coffin Texts: Spell 474:

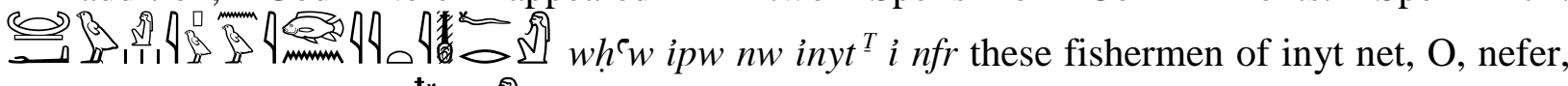
and Spell $683^{\dagger}$ is written 6 这 (De Buck and Gardiner, 1956)

During the New Kingdom the name of the God Nefer was written with one of his titles in the tomb of sn-nfr (TT 96): of visibility (eyesight) (Eggebrecht, 1986; Lüscher, 1998; Calmettes, 2007).

In an unpublished papyrus at Cairo Museum ${ }^{\dagger}$ CG 58007 (Fig. 1) which dates back to the $19^{\text {th }}$ Dynasty, Nefer is listed between the members of the Small Ennead as follows:

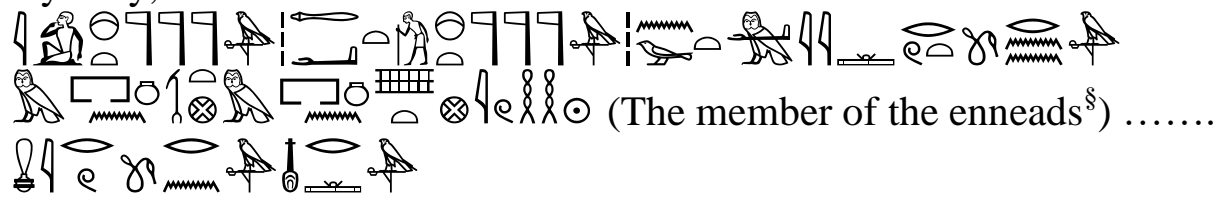

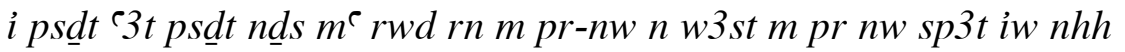
mi rwd rn nfr. O, the great Ennead, O, the small Ennead, Your name was strong in the chapel (Pr-nw) at Thebes in the chapel of spat forever....... like the strength of the name of Nefer.

In addition, the god nefer was mentioned in a ritual of plague (Smith Surgical Papyrus)

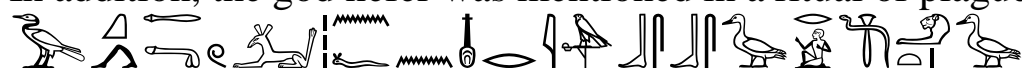

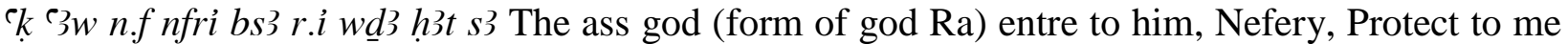
the fresh forepart of son (Smith, 1930; Leitz, 2002).

\footnotetext{
* Leitz mistakenly read as fdw.

$\dagger$ The outer coffin of DHwt nxt from El-Bersha, Now (Boston 20.1822-27).

*Unpublished papyrus at Cairo Museum, CG 58007, many thanks to Dr. M. Nassar at Faculty of Archeology, Fayoum University, that he showed me this papyrus.

$\S$ All the members of the small Ennead preceded Nefer except one the god Min, for more details about the small Enead look: Sethe, 1905; Barta, 1973).
} 
The second way, He inscribed without the determinative of god but the meaning showed an indication of god as follows: In the Old Kingdom, he was mentioned in the Pyramid Texts Spell (820b): $\overbrace{}^{2}-1$. of whom his mother has spoken "Heir", as his father said" (Samuel, 1952; Faulkner, 1978; Timofey, 2012).

Furthermore, his name appeared during the Graeco-Roman period on the Sarcophagus of $t 3 h w^{*}$

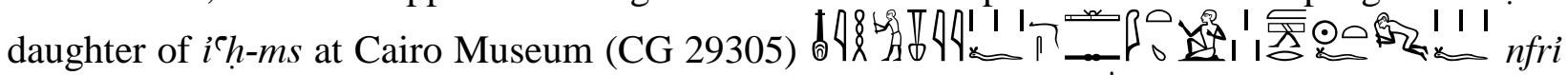
hw sm3yt.f nysw m3`tyw šm $r$ hftyw.f Nefery, who strike his smayt ${ }^{\dagger}$ (Fig. 2). With the help of righteous $\left(m 3^{\top} t y w\right)^{\ddagger}$, (he) go to his enemies (Maspero and Gauthier, 1908-14; Leitz, 2002).

It was worth mentioned that the iconographic of Nefer as a god was shown on the Sarcophagus of $t 3 h w$ daughter of $i c h-m s$ at Cairo Museum (CG 29305) (Fig. 3). He was depicted as a human figure holding $w 3 s$ and ' $n h$ scepters (Fig. 4) (Maspero and Gauthier, 1908-14; Goyon, 1985).

\section{The term nefer in gods' description}

The term nefer was listed in descriptions of various gods as follows:

A. Buchis:

In a stela of Ptolemaic VI (line 7) (Fig. 5) the term nefer appeared in the description of god Buchis.

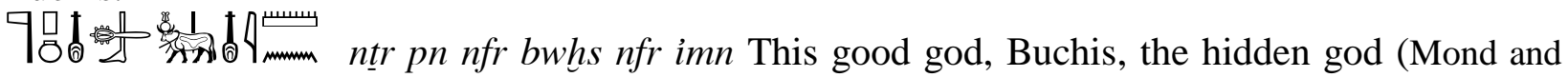
Myers, 1934).

B. Min:

In the description of God Min (or gods attributes with Min as Amun, Kamutef), the term nefer was appeared. The god Min was described as his beauty" (Wilson, 1997).

C. Osiris Wn-nefer:

The name means "he who is everlastingly good condition" (Wilkinson, 2003). Nefer in Osiris titles refer to god's physical well-being, youthfulness and renewed his vigor (Smith, 1987) or refer to Osirian resurrection (Donohue, 1978). The text as follows:

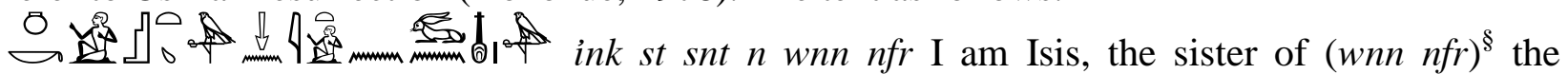
beneficence of Osiris (Goyon, 1999).

In addition, the god Osiris was described as 129 ntr nfr the kind god or the Perfect god (Tillier, 2011), 4049㒀每 ity $n f r$ the good Sovereign and man (Cauville, 1997). It can be noted that the name of the god Osiris Wn-nefer was written at Dendara Temple as 1 (Valures, 1988).

\footnotetext{
* Leitz mistakenly mentioned it as Dd Hr son of iaH ms

${ }^{\dagger}$ They were the allies of god Seth.

* mAatyw were minor gods associated with the sun god Ra, and they were the men of Maa't (Wilson, 1997, Chassiant, 1933).

${ }^{\S}$ This is one of the names of Osiris in the Graeco-Roman period, he was written inside a cartouche details look: (Chassiant, 1965; Favard, and Meeks, 2012; Traunecker, 2012).
} 
D. Osiris Sokar:

In the temple of Deir Chelouit, the inscription of the naos described the god Osiris Sokar in line 4 as (Fig. 6):

A 4 月 šm .k 'nhw.t $r$ t ${ }^{\text {' }}$ 'nht ir.k st.k The happenies is to you twice, ...... you lead you their lives to your tomb and made your place (cemetery) (Zivie, 1986).

E. Sia:

The Ptolemaic addition at El-Kab Temple revealed the king on the walls of the court in front of Nekhbet and Sia (Fig. 7) while the text described the god Sia with the good

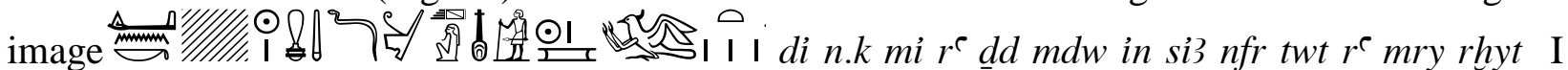
gave to you ... as analogy with Re, Words spoken by Sia, the good image of Ra who Rekhyt birds love (Derchain, 1971).

F. Sopdu:

The temple of Hibis at El-Kharga oasis, Contained an incorporated text of a scene (Fig. 8), on West Wall of the hypostyle hall. The scene shows the king in front of Sopdu and the collateral text refers to Sopdu as the good one.

in 4 S son of eastern Horus (Davies, 1953).

G. Wpwawt:

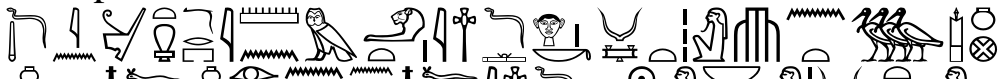

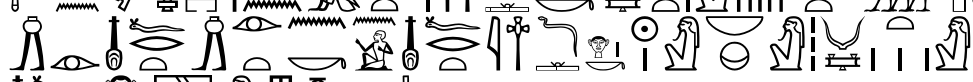

(1)

dd $m d w$ in htm imy-r pr imn $m$ h't i nd hr.k wp w3wt hnt nt b3w iwn in ir nfr in irt n.k n.i nfr I nd $h r . k R^{\top} n b$ psdw wp w3wt nfr hr šf hnt $3 b d w$

Words were spoken by the royal seal bearer, the director of the house, Amenemhat "salute to Wepwawt who is in front of the spirits of Heliopolis, O, you bring and make good, bring which you made good. Salut to Ra, the lord of the Ennead, Wepwawt the good, Hershaef who is in front of Abydos" (Hassan, 1928).

Finally, there were a lot of gods who's their names contain the term nefer ${ }^{*}$ such as the god Nefertem the third member of Memphis triad t he has newly appeared is perfect" (Winger, 2000) and $\mathrm{O}_{\text {O }}$ Q guardian snake (Wilson, 1997).

\section{The term nefer in places' names}

The tern nefer was incorporated between Ancient Egyptian names of places such as pyramids, temples and settlement or villages. The name of the capital of the Old Kingdom was Memphis (mn nfr $\triangle$ which means the white enclosur (Gauthier, 1925). Moreover, there were some village or settlement had the term nefer in their names such as place (Menuf nowadays, Menoufia Governorate) (Gauthier, 1927), 13: iw nfrt north west

\footnotetext{
* For details about these gods look: Leitz, 2002, PP. 207- 235.

${ }^{\dagger}$ This snake protected Osiris in the afterlife.
} 
of Thebes (Gauthier 1925), and 13 nfrwsy village in the $15^{\text {th }}$ Nome of Upper Egypt, north of Elkom El-Ahmar (Gauthier, 1927).

Some pyramids of the Old Kingdom had the term nefer between their names for instance the pyramid of King Ounas (Gauthier, 1927), the pyramid of the king Pepy I beautiful, and the pyramid of king Meryenra $\odot{ }^{\infty}$ Meryenra is rising (Gauthier, 1927).

Edfu Temple is called in the temple description of the child (Wilson, 1997). Furthermore the name of Osiris Temple at Dendera is known as ๑ iw nfrt 45 (Brugsch, 1879).

\section{The term nefer in personal names}

The term nefer appeared in personal names of officials as well as kings. There were a lot of names of officials whose their names $n f r$ only $t^{2}$ (Ranke, 1935). It can be observed that this name was named throughout the Ancient Egyptian History (Ranke, 1935, 1952).

Some official had the term nefer between their names such as: in the Old Kingdom $n f r$ š̌m (Lepsuis, 1849), tor nfr tm (Mariette, 1885),

The Middle Kingdom coupled with the New Kingdom personal name had the term nefer for instance:

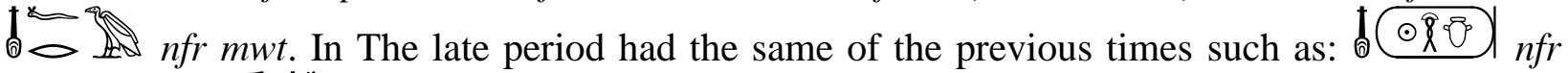
whi ib r and $r^{\circ}$ Wnn $n r^{*}$ (Ranke, 1935).

The coronation names of Egyptian Kings (Gauthier, 1907 and 1912) contained the term such as: (๑) $n f r k 3 r^{c} 6^{\text {th }}$ king of the second Dynasty,

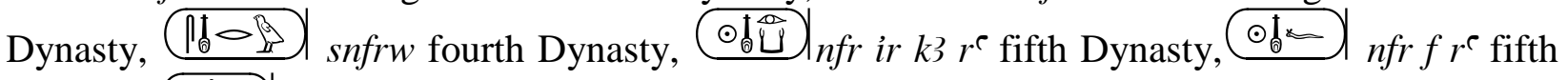
Dynasty, $\odot$ 过 $n f r k r^{\circ}$ Pepi II.

In the Middle Kingdom the Queen Neferwptah of $12^{\text {th }}$ Dynasty nfrw pth (Gauthier, 1907).

In the Second Intermediate Period king $\overbrace{}^{c} n f r r^{c}$ King Sobekhotep IV $13^{\text {th }}$ Dynasty and $\odot$ ๑ण $n f r$ ib $r^{\ulcorner} 14^{\text {th }}$ Dynasty, had the term in their names (Gauthier 1912). The New Kingdom

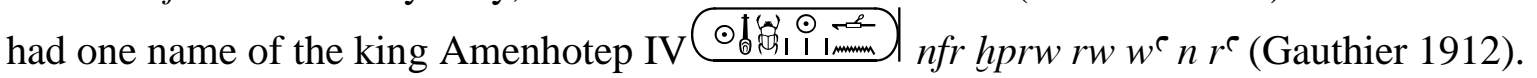

* wnn-nfr (w), the imperfective participle of wnn, "'to be", + nfr in the old perfective, was employed in the Fifth Dynasty as a personal name. It was known as a divine epithet from the beginning of the Twelfth Dynasty (Donohue, 1978). 
The late Period had two kings whose nefer was incorporated between their names, the first was the king Shbaka (25 Dynasty) Ut॰ $n f r k^{c} r^{c}$ and the king Pasmatek II (26 Dynasty) $n f r i b$ $r^{\complement}$ (Gauthier 1912). It can be noted that there is one birth name of the king Neferhotep htp $13^{\text {th }}$ Dynasty who had nefer in his name (Gauthier 1912).

In addition, the term was listed in female names such as: Jedefra (Gauthier, 1907), (Gauthier, 1912), ब Nefertiti Wife of King Amenhotep IV (Gauthier, 1912), Queen Nefertari Wife of King Ramses II (Dodson, 2004; Grajetzki, 2005), (Ranke, 1935), and ब』。 nfrt ist (Ranke, 1952).

\section{The term nefer in personal titles}

The royal titles together with personal titles had the term nefer. The title known as a royal title than as a divine epithet; nevertheless, many deities are called $n t r n f r$. The most frequent and ancient god was Osiris.

It was one of the most famous titles of king all over the Ancient Egyptian History especially in the Ramessid era. There were a lot of king who was taken this title such as Khaefra $4^{\text {th }}$ Dynasty, Mentouhotep II $11^{\text {th }}$ Dynasty (Gauthier, 1907), Sobek Hotep III $13^{\text {th }}$ Dynasty (Gauhtier 1912), Ahmose $18^{\text {th }}$ Dynasty (Gauthier, 1912), and Ramses II $19^{\text {th }}$ Dynasty (Kamal, 1952).

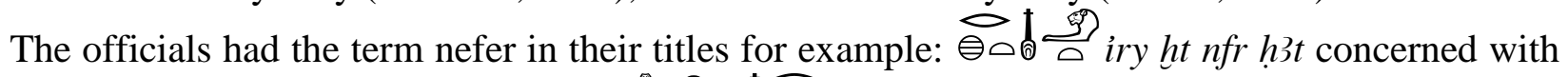
the affairs of the crown (Jones, 2000),

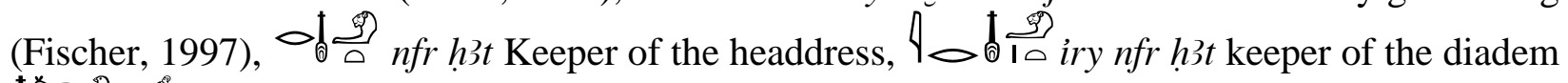

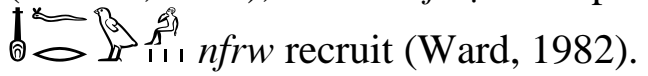

Finally the term nefer listed between the funerary titles such as $\square_{\mathrm{I}} \mathrm{f} \mathrm{pr-nfr}^{+}$funerary workshop (Donohue, 1978; Ward, 1982).

\section{Discussion and results}

The term of nefer was used to deliver the concepts of goodness and beauty and comeliness. Furthermore, the meaning was varied according to the determinative. The term was used as Adjective such as $s p n f r$ (good event), noun such as $b w n f r$ (beauty), Adverb for instance $r$-nfr (in good part), and verb such as nfr.n.i It went well with me.

The term nefer as a god was written in texts with Horus determinative and god sitting one hand. On the other hand, he was inscribed without determinative of god but the meaning refer to the god.

\footnotetext{
* The word $n f r$ is appeared in the epithets of gods. In the First Intermediate Period, the presence of $\mathrm{nTr}+\mathrm{nfr}$ alone was virtually obligated to Osiris or Anubis (Dunham, 1937; Petrie and Murray, 1952; Fischer, 1968).

${ }^{\dagger}$ It was connected with the purification of the body (Grdseloff, 1941). It was appeared and performed in tombs from at least the Fourth Dynasty onwards (Hassan, 1943; Junker, 1944). In contrast, the phrase pr-nfr in inscriptions appears not to have been introduced before the end of the Old Kingdom (Seth, 1903; Ricke, 1950; Settgast, 1963).
} 
Furthermore, the god Nefer was considered the god of the necropolis in Pyramid Texts, spell (820b). He had a candid title listed in the tomb of $̌ n-n f r$ (TT96) $n f r n b m 33$ the lord of seeing. The god nefer was mentioned in some gods description such as Wepwawet (the god who stand equal with Anubis in two side of Osiris (chapter 138 book of the dead) (Quirk, 2013), the underworld gods Osiris wen-nefer and Osiris Sokar, Buchis (thresh in the afterworld (Wilkinson, 2012), Sia (stands in the right of god Ra and held the god's sacred papyrus scroll (Wilkinson, 2012), Sopdu (equated with the teeth of the dead king (Wilkinson, 2012), and Horus Behdety. Therefore, it can be observed that the god Nefer was one of the gods of the afterworld.

The term nefer was coupled with pyramids' names of the Old Kingdom, Temples, and Ancient places specially Memphis.

The term nefer was prevalent in Egyptian Kings' coronation names. It was listed in the Old kingdom, Middle Kingdom, Second intermediate Period, New Kingdom and Late Period. In addition, it was mentioned in some Queen such as Nefertiti the wife of Amenhotep IV.

The term nefer was common in male names as well as female one. The term nefer was put beside the name of king such as $n f r h r$ snfrw, name of god or goddess such as $n f r$ imn and Nfr iw hthrr, and name of job such as $n f r$ šr.

The personal titles contain the term nefer such as $n f r$ h $3 t$. Moreover, it was listed in the most famous kings' titles in Ancient Egyptian Civilization $n \underline{t} r$ nfr.

Finally, the term nefer in personal names or titles, Griffith (1966) pointed out that nefer in personal names refers to ethical or moral aspects and the beneficence of Osiris. It may have been a derived sense parallel to the moral implications of $m{ }^{3} t$ (Fecht, 1958).

\section{Conclusion}

The current study presented the term nefer in ancient Egyptian conception. The term nefer was very popular throughout the ages with the Ancient Egyptians. It had various meaning according to the determinative. The meaning was coupled with appearance, quality, characters, conditions, fixed expressions. In addition, the term was used as verb, noun, addictive, and adverb.

The term was used as a god who had one title (the lord of seeing). The study suggested that god was the god of the necropolis, so he was one of the gods of the afterworld.

Nefer was also incorporated into the description of Ancient Egyptian gods as Buchis, Osiris, Osiris Sokar, Sia, Sopdu and Wpwawt. In addition, He was connected with the small Ennead.

The titles of kings and officials were held the term nefer. $n t r r$ fr was the most famous title of kings as well as gods. Official held many titles in which the term nefer was involved such as $n f r w$ recruits (young men of the army), and iry $n f r$ h $3 t$ keeper of the diadem

This term appeared within many personal names of kings, Queen, and Officials, including those of the famous king as Snefrw and Amenhotep IV, queens as Nefertiti and Nefertari. It can be observed that the term nefer is used during the Old Kingdom in kings' names and places more than any times in Ancient Egyptian History.

\section{References}

Allen, J., (2010). Middle Egyptian: An Introduction to the Language and Culture of Hieroglyphs, Cambridge.

Barta, W., (1973). "Unterauchungen Zum Gotterkeise der Neunbeit", MAS 28, PP. 53- 58.

Bates, R., (2004). A Dictionary of Middle Egyptian for Student of Biblical Archeology and Old Testament Studies, USA.

Breasted, J., (1930). The Edwin Smith Surgical Papyrus, Oxford. 
Brich, S., (1967). Dictionary of Hieroglyphics, London.

Brugch, H., (1868). Dictionnaire des Hieroglyphique et Dėmotique, Partie II, Paris.

Brugch, H., (1879). Dictionnaire Gẻographique del'Ancienne Égypte, Partie I, Leipzig.

Calmettes, M., (2007). "La Tombe de Sennefer, Réflexions sur le Programme Décoratif du Caveau (TT 96B)", Revue Égypte, Afrique \& Orient N45, PP. 53- 64.

Cauville, C., (1997). Le Temple des Dendera, Les Chapelles OSiriennes, Index, Le Caire.

Chassiant, E., (1933). Le Temple de Edfu, Vol. VI, Le Caire.

Chassiant, E., and Dumas F., (1965). Le Temple de Dendara, Vol. VI, Le Caire.

Davies , N., (1953). The Temple of Hibis at El-Gharga Oasis, Vol. III, London, New york, England.

De Buck A., and Gardiner, A., (1956). The Ancient Egyptian Coffin Texts VI, OIP 81, Chicago.

De Buck, A. Gardiner, A.,(1950). Miscellanea Academica Berolinensia , Berlin.

Derchain, Ph., (1971). El Kab, Vol. I, Les Monuments Religieux al'entree d'Ouday Hellal, Bruxelles.

Dickson, P., (2006). Dictionary of Middle Egyptian in Gardiner Classification Order, USA.

Dodson, A. and Hilton, D., (2004). The Complete Royal Families of Ancient Egypt, London.

Donohue, V., (1978). "Pr- nfr", JEA 64, PP. 141- 160.

Dunham, D., (1937). hiaga-ed-Dtr Stelae of the First Intermediate Period, London.

Eggebrecht, A., (1986). "Sen-nefer ", Die Grabkammer Des Burgermeisters Von Theben, Mainz.

Erman, A. and Grapow, H. (1971), Wörterbuch der ägyptischen Sprache. Band II, Berlin.

Faulkner, R., (1978). Ancient Egyptian pyramid Texts, Vol. III, London.

Faulkner, R., (1988). A Concise Dictionary of Middle Egyptian, Oxford.

Favard, Ch., and Meeks, D., (2012). "Les Corps Osirriens: du Papyrus du Delta au Temple de Behbeit", in: Coulon, L. (ed.), Le Culte d'Osiris au $1^{\text {er }}$ Millènaire av. J.C., Lyon.

Fecht, G., (1958). Der Habgierige und Maat in der Lehredes Ptahhotep ,Gliickstadt.

Fischer, H., (1968). Dendera in the Third Millennium B.C., New York.

Fischer, H., (1997). Egyptian Titles of the Middle Kingdom: A Supplement to Wm. Ward Index, New York

Gardiner, A., (1994). Egyptian Grammar, Third edition, Oxford.

Grajetzki, H., (2005). Ancient Egyptian Queens: A Hieroglyphic Dictionary, London.

Gauthier, H., (1907). Le Livre des Rois D'Égypt, Part I, Le Caire.

Gauthier, H., (1912). Le Livre des Rois D'Égypt, Part II, Le Caire.

Gauthier, H., (1925). Dictionnaire des Nomes Géographiques, Vol. II, Le Caire.

Gauthier, H., (1927). Dictionnaire des Nomes Gėographique, Vol. III and IV, Le Caire.

Goyon, J., (1985). Les Dieux Geadiens et le Genese des Temples, Vol. I, II, Le Caire.

Goyon, J., (1999). Le papyrus d'Imouthès Files des Pesintâes Au Metropolitan Museum of Art de New-York (Papy. MMA 35.9.21), New York.

Grdseloff, B., (1941). Das Ägyptische Reinigungszelt, Cairo.

Griffiths, G., (1966). The Origins of Osiris and his Cult, Berlin.

Griffiths, G., (1970). Plutarch's De Isiside et Osiride, Cardiff.

Griffith, G., (2000). "Osiris", in: Redford, D. (ed.), the Oxford Encyclopedia of Ancient Egypt, Vol. II, Cairo, PP. 615-19.

Hassan, S., (1928). Hymnes Religioeux du Moyen Empire, Le Caire.

Hassan, S., (1943). Excavations at Giza, IV , Cairo.

Jones, D., (2000), An Index of Ancient Egyptian Titles, Epithets and Phrases of the Old Kingdom, Vol. I, Oxford.

Junker, H., (1944). Giza,VII ,Vienna.

Kamal, A., (1907). "Rapport sur une Inscription Faite A Tell El-Waqa", ASAE 8, PP. 1- 50.

Kamal, A., (1952). "Foullies à Dara et Qocier El-Amarna", ASAE 12, PP. 127- 144. 
Leitz, Ch. (2002). Lexikon der Ägyptischen Götter und Götterbezeichenungen, Band IV, Leuven, Paris.

Lepsuis, R., (1849). Denkmäeler au Aegypten und Athiopien, Band II, Berlin,.

Lesko, L. and Barbara, S., (2002). A Dictionary of Late Period, USA

Lüscher, B., (1998). Untersuchungen zu Totenbuch Spruch 151, Wiesbaden, PP. 136- 137.

Loprieno, A., (1995). Ancient Egyptian: A Linguistic Introduction, Cambridge.

Lutz, H., (1927). Egyptian Tombs Steles and Offering Stones, Leipzig.

Mariette, A., and Maspero, G., (1885). Les mastabas de l' Ancienne Empire, Paris.

Maspero, G. and H. Gauthier, (1908-1914). Sarcophages des ėpoques Persane et Ptolèbmaique, Le Caire.

Mond, R. and Myers O., (1934). The Buchesum, Vol. II, III, The Hieroglyphic Inscriptions, London.

Montpellier, 1988.

Petrie, F., and Murray, M., (1952). Seven Memphite Tomb Chapels, London.

Quirke, S., (2013). Going Out in Daylight prt $\mathrm{m}$ hrw, The Ancient Egyptian Book of the Dead, Translations, Sources and Meaning, London.

Ranke, H., (1935). Die ägyptischen Personennamen, Band I, Glückstadt.

Ranke, H., (1952). Die ägyptischen Personennamen, Band II, New York.

Reisner, G. and Smith, S., (1955). A History of the Giza Necropolis, Vol. II, Cambridge.

Ricke, H., (1950). Bemerkungen zur iigyptischen Bazikunst des Alten Reiches, Band II, Cairo.

Samuel, M., (1952). The Pyramid Texts, in Translation and Commentary, London,.

Schulman, R., (I964). Military Rank, Title, and Organization in the Egyptian New Kingdom, Berlin.

Seth, K., (1903). Urkunden dea Alen Reiches, Leipzig.

Sethe, K., (1905). Bettrage suralteaten Geschicht Ägyptines, Untersure hun en Surgechichte und Altertumkunde, Agypten, Band III, Leipzig.

Settgast, J., (1963). Untersuchungen zu altagyptischen Bestattungsdarstellungen, Glückstadt.

Smith, M., (1987). The Demotic Papyri in British Museum, Vol. III, The Mortuary texts of Papyrus 10507, British.

Stock, H., (1951). NTr nfr = Der gute Gott, Hildesheim.

Tillier, A., (2011). "A report on the nTr nfr as a divine epithet: Contribution to the study of King Osiris in the Middle Kingdom", Revue d'égyptologie 62, PP. 159-174.

Timofey Sh., (2012). Critical Analysis of J. Allen's "The Ancient Egyptian Pyramid Texts", OmskTricht.

Traunecker, C., (2012). "La Chapelle d'Osiris:Seigneur de l'èternitè-neheh" à Karnak", in: Coulon, L. (ed.), Le Culte d'Osiris au $1^{\mathrm{er}}$ Millènaire av. J.C., Lyon.

Valures Phoneethiques des Signes Hieroglyphiques D'Époque Greco-Romaine Montpellier, 1988.

Ward, W. A. (1982). Index of Egyptian Administrative and Religious titlesof the Middle Kingdom, Beirut.

Wilkinson, R., (2003). The Complete Gods and Goddesses of Ancient Egypt, London.

Wilson, P. (1997), A Ptolemaic Lexicon: a Lexicographical study of the Texts in the Temple of Edfu, Leuven.

Wilson, P., (1997). A Ptolemaic Lexicon: a Lexicographical study of the Texts in the Temple of Edfu, Leuven.

Winger, H., (2000). "Nefertum" in: Redford, D. (ed.), the Oxford Encyclopedia of Ancient Egypt, Cairo, PP. 514- 551.

Zivie, Ch., (1986). Le Temple de Deir Chelouit III, Inscription de naos, Cairo. 


\section{Figures}

Fig. 1: Unpublished papyrus of the Small Ennead (Cairo Museum C.G. 58007).

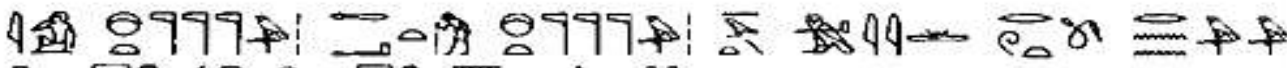

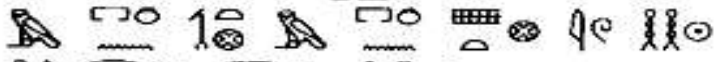

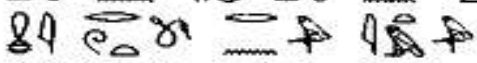

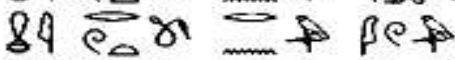

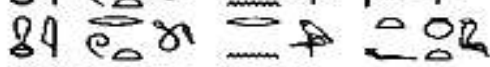

84 C.

$84 e_{0} x \equiv+0.0 \%$

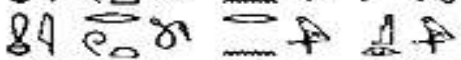

84 e० $_{0}=1.02$

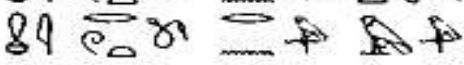

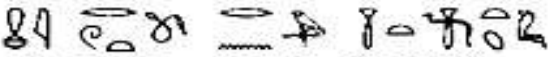

$84 c_{0} x \equiv+70 R$

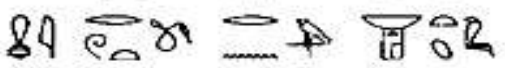

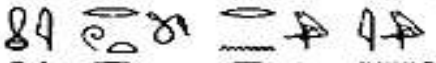

$84 \stackrel{P}{c} x=A$

84 cor $=10$ क

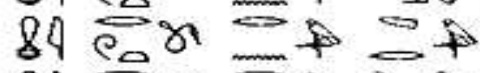

81 er $=7.7000$

$81 \mathrm{C}_{0} x$ 三十

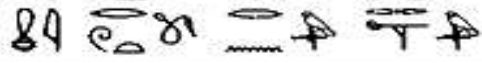

Fig. 2: sm3yt as depicted on the wall of Edfu Temple (Goyon,
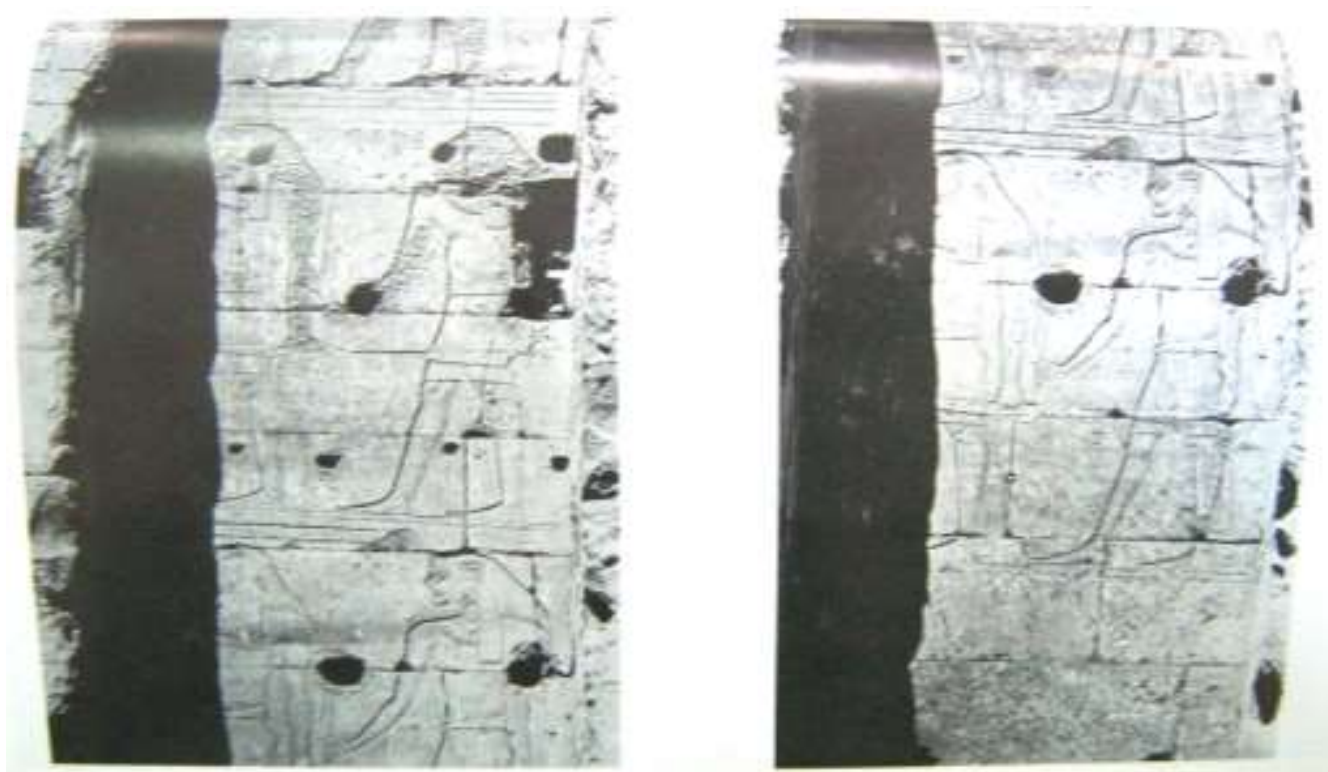
Fig. 3: The Iconography of God Nefer which depicted on the Sarcophagus of $t 3 h \mathrm{hw}$ daughter of ich-ms at Cairo Museum (CG 29305) (after the courtesy of the Egyptian Museum).

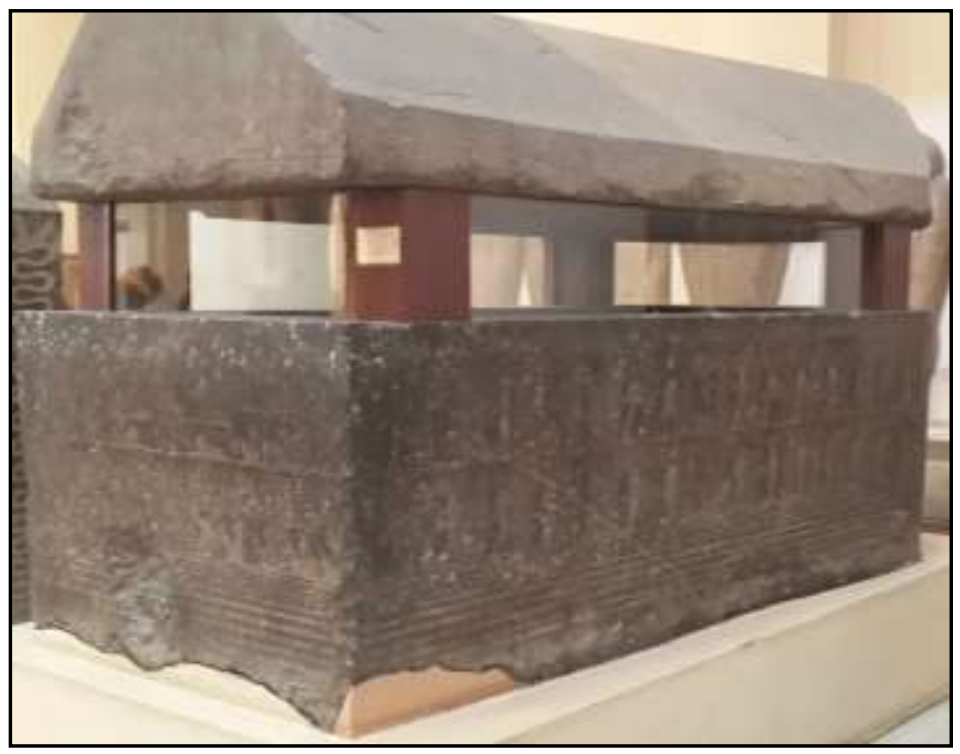

Fig. 4: The iconography of God Nefer the Sarcophagus of $t 3 h w$ daughter of $i$ h $h-m s$ at Cairo Museum (CG 29305) (after the courtesy of the Egyptian Museum).

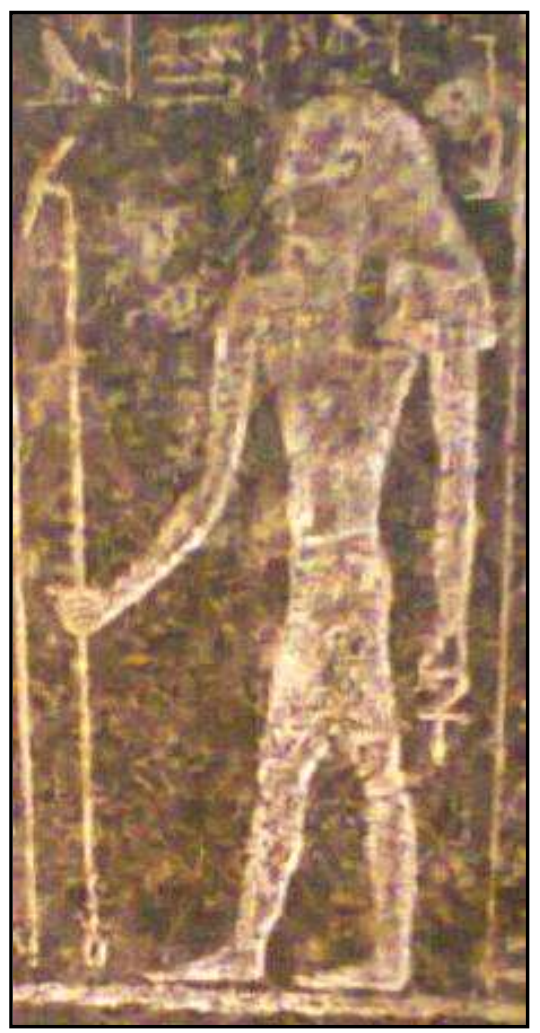


Fig. 5: A Stela of Ptolemaic VI, and the text which written on it (Mond and Myers, 1024 D1 XI I

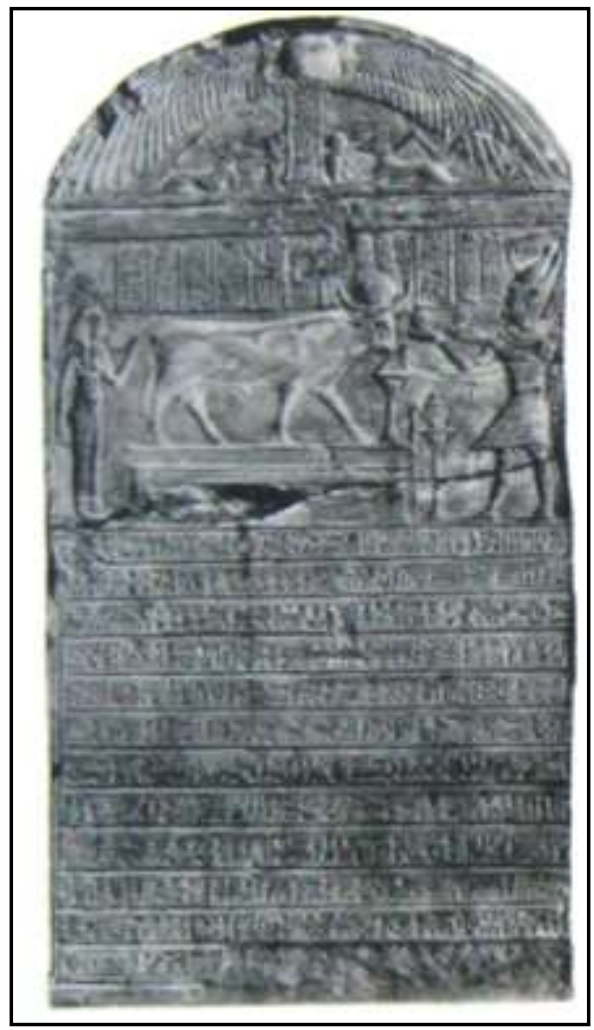

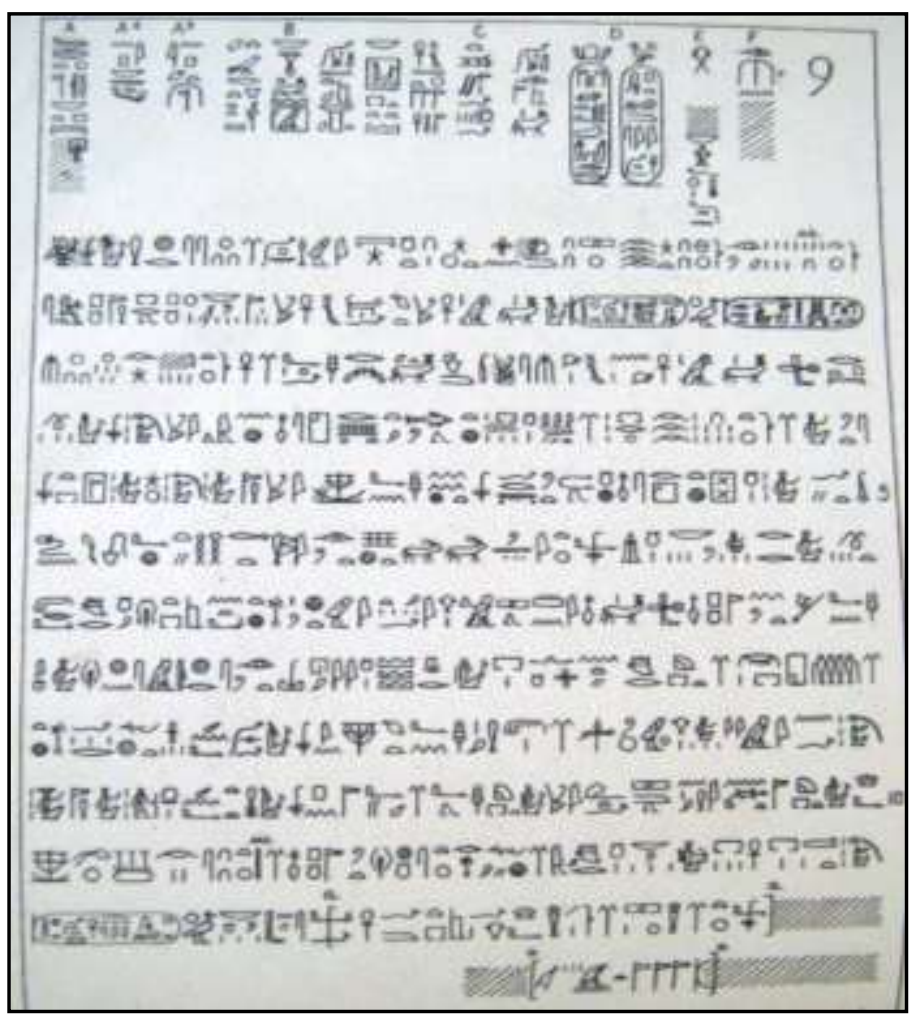

Fig. 6: The Inscription of the Naos of of Deir Chelouit Temple (Zivie, 1986. PL. 13).

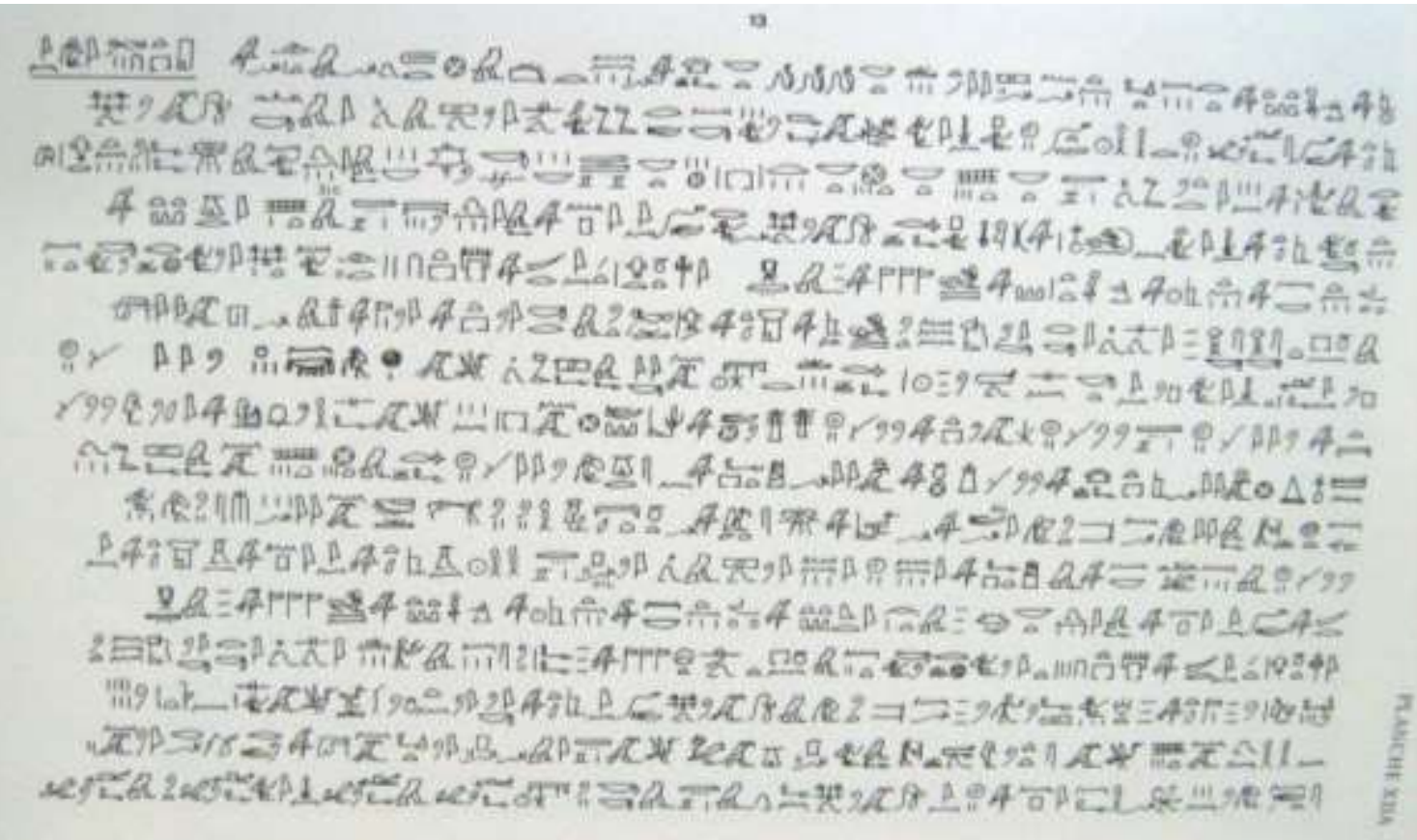


International Journal of Heritage, Tourism and Hospitality Vol. (12), No. (1/2), March, 2018 By: Faculty of Tourism and Hotels, Fayoum University

Fig. 7: Scene on the Walls of the Court (Ptolemaic addition), the king is shown in front of Nekhbet and Sia (Derchain, 1971, PL. 11).

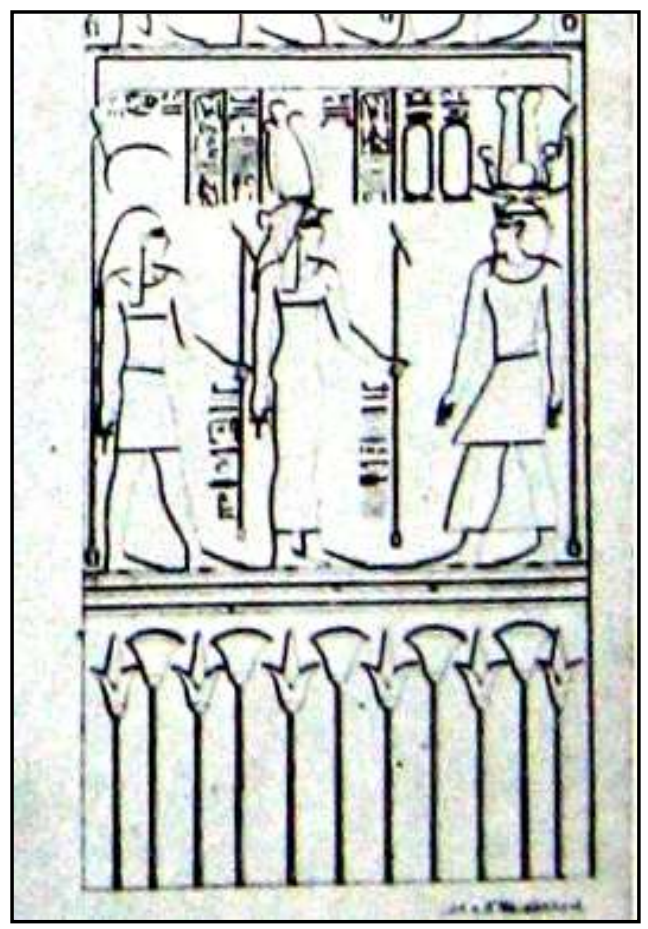

Fig. 8: West Wall of the Hypostyle Hall, Temple of Hibis at El-Kharga Oasis, (Davies , 1953, PL. 8).

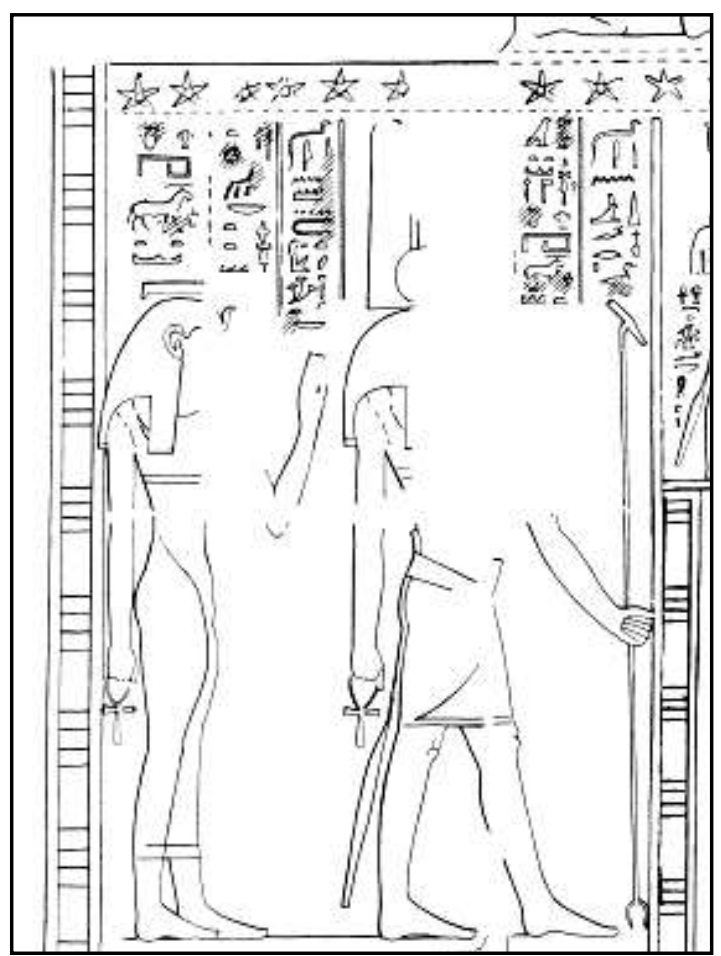

